ISSN : 2087-2461

PENANGGUNG JAWAB Dekan FIKOM Trimanah, M.Si

Sekretaris Fakultas

Dian Marhaeni K, M.Si

Ketua Penyunting Made Dwi Adnjani, M.Si

Sekretaris

Mubarok, M.Si

Bendahara

Parwati, SH

Dewan Penyunting

Edi Ismoyo, M.Si

Drs. Haryoso

Seksi Usaha

Endang Winarsih, S.Sos

Sirkulasi dan Distribusi

Palupi Satwika, Amd.

Alamat Redaksi

Fakultas Ilmu Komunikasi

Universitas Islam

Sultan Agung Semarang

Jl. Raya Kaligawe Km. 4

Po. Box 1054/SM

Semarang 50112

Telp. (024) 6583584

ext. $448 / 449$

Fax. (024) 6582455

email : jurnalfikom@yahoo.com
Konstruksi Teori Komunikasi Dalam Tafsir Al Qur'an Surat Al Fatihah

Mubarok

mubarok@unisula.ac.id

$110-127$

Inovasi Komunikasi Pemasaran Pada RRI Semarang

Agus Triyono

agustriyono7@gmail.com

128-136

Pengaruh Word of Mouth dan Brand Awareness terhadap Intensi Mengunjungi Tempat Wisata Ziarah Makam Sunan Kalijaga Demak

Santi Ratnawati

santirahmawati@ymail.com

$137-148$

Pengaruh Persepsi Downline Tentang Kualitas Jasa Upline Pada Multi Level Marketing Tianshi Terhadap Loyalitas Downline di Malang

(Studi pada jaringan Akhmad Fidzan)

Devi Purnamasari

devi.purnamasari9@g mail.com

149-163

Manajemen Krisis Polri dalam Kasus Penyerangan Lembaga Permasyarakatan Cebongan Sleman Daerah Istimewa Yogyakarta

Iva Anjar Pawestri

iva.anjar89@yahoo.co.id

$164-180$

Identitas Diri Remaja Melalui Status Sosial Facebook

Muna Madrah

munamadrah@unissula.ac.id.

Made Dwi Adnjani

made@unissula.ac.id

$181-198$

Efektifitas Pelaksanaan Kebijakan Joko Widodo dalam Mengentaskan Kemiskinan (Studi Opini Pemegang Kartu Jakarta Sehat dan Kartu Jakarta Pintar di DKI Jakarta)

Indah Suryawati

indahsuryawati_2121@yahoo.com 199-218 


\title{
KONSTRUKSI TEORI KOMUNIKASI DALAM TAFSIR AL QUR'AN SURAT AL FATIHAH
}

\author{
Oleh: \\ Mubarok \\ Fakultas Ilmu Komunikasi Unissula Semarang \\ mubarok@unissula.ac.id
}

\begin{abstract}
Abstraksi
Teori komunikasi merupakan bangunan teori yang bersumber dari interdisipliner resource (sumber-sumber yang saling berkaitan) dengan percampuran dari ilmu sosiologi, psikologi, pengetahuan alam, matematika, dan sumber lain yang membantu perkembangan ilmu komunikasi. Perkembangan sebagai sebuah ilmu melibatkan penelitian dasar yang berasal dari berbagai cabang ilmu dengan sumbangan pemikiran dan gagasan yang memperkaya konstruksi teori komunikasi. Teori dikonstruksikan melalui proses yang dikenal dengan inquiry. Untuk bisa memahami suatu teori maka diperlukan pemahaman awal terhadap proses inquiry. Inquiry adalah sebuah studi sistematis tentang pengalaman yang mengarah kepada pemahaman, pengetahuan dan teori. Dalam pandangan Islam kegiatan komunikasi tidak hanya membentuk pola hubungan antar manusia tetapi membentuk pola kedekatan hubungan antara manusia dengan Rab-nya. Sekulerisasi pemahaman untuk memisahkan kegiatan komunikasi antara manusia dengan manusia membuat pemahaman komunikasi terbatas pada aspek manifest. Pertanggungjawaban terbesar komunikasi manusia adalah dengan Rab-nya sehingga pemahaman ini menjadi dasar dari kegiatan komunikasi dalam Islam. Berkomunikasi dengan sesama manusia tidak bisa dibatasi dengan penilaian aspek manifest semata. Salah satu surat dalam Al Qur'an yang memiliki banyak pengaruh bagi kehidupan manusia adalah surat Al Fatihah. Surat ini wajib dibaca minimal tujuh belas kali sehari semalam oleh setiap muslim dalam sholatnya. Dalam surat ini digambarkan proses komunikasi antara hamba dengan RabNya. Proses komunikasi transenden tersebut menjadi dasar pola komunikasi dari setiap muslim dengan orang lain.
\end{abstract}

\section{Abstract}

Communication theory is a theory that comes from building an interdisciplinary resource (the sources of inter-related) with a mixture of sociology, psychology, natural science, mathematics, and other resources that help the development of science communication. The development as a science involves basic research from different disciplines to contribute thoughts and ideas that enrich the communication theory construction. The theory is constructed through a process known as inquiry. To be able to understand a theory would require an initial understanding of the inquiry process. Inquiry is a systematic study of the experiences that led to the understanding, knowledge and theory. In the Islamic view of communication activities form a pattern not only human relations but form a pattern of close relationship between man and his Rab. Secularization of understanding to separate the activities of communication between man and man makes understanding the communication is limited to aspects of the manifest. Accountability is the greatest of human communication with her so that Rab has become a basic understanding of communication activities in Islam. Communicate with fellow human beings can not be limited solely to manifest aspects of assessment. One of the letters in the Qur'an that has many implications for human life is surah Al-Fatihah. This letter shall be read at least seventeen times a day by every Muslim in prayer. In this letter described the communication 
process between His servants with Rab. The transcendent communication process is the basis of every Muslim communication patterns with others

\section{A. Pendahuluan}

Teori komunikasi merupakan bangunan teori yang bersumber dari interdisipliner resource (sumbersumber yang saling berkaitan) dengan percampuran dari ilmu sosiologi, psikologi, pengetahuan alam, matematika, dan sumber lain yang membantu perkembangan ilmu komunikasi. Perkembangan sebagai sebuah ilmu melibatkan penelitian dasar yang berasal dari berbagai cabang ilmu dengan sumbangan pemikiran dan gagasan yang memperkaya konstruksi teori komunikasi.

Di Indonesia, ilmu komunikasi telah dipelajari lebih dari setengah abad melalui lembaga-lembaga pendidikan tinggi. Perguruan tinggi pertama yang menyelenggarakan pendidikan komunikasi adalah Akademi Ilmu Politik Yogyakarta pada tahun 1949 yang kemudian menjadi Bagian Sosial Politik dari Fakultas Hukum Universitas Gadjah Mada (UGM). Perguruan tinggi ini sekarang kita mengenalnya sebagai Jurusan Ilmu Komunikasi FISIPOL UGM. Jika dilihat perkembangannya hingga sekarang ini, jumlah perguruan tinggi di Indonesia yang menyelenggarakan pendidikan komunikasi semakin meningkat secara kuantitas. Di berbagai wilayah, dapat dengan mudah dijumpai perguruan tinggi ilmu komunikasi, tidak saja di di kota-kota Pulau Jawa, tetapi telah menyebar ke Sumatera, Bali, Nusa Tenggara, Kalimantan, Sulawesi, Maluku hingga Papua (Rahardjo, 2012:558).

Perkembangan ilmu pengetahuan, khususnya ilmu komunikasi, di Indonesia masih sangat lambat. Salah satu penyebab, menjadi peneliti komunikasi belum pilihan utama para sarjana komunikasi kita. Selain itu, hasil penelitian komunikasi tidak mendapat dukungan kuat dari instansi pemerintah maupun swasta. Orang yang bekerja di Litbang komunikasi justru kesejahteraannya lebih rendah dibanding yang memegang jabatan struktural bidang komunikasi. Oleh karena itu, hasil penelitian komunikasi di Indonesia sangat sedikit dan belum mempunyai daya saing global. Realitas menunjukkan, perilaku sebagian (tidak sedikit) ilmuan kita yang membuat hati miris.

Pemikiran teoritik Komunikasi Barat yang banyak diterapkan dinegaranegara Asia termasuk Indonesia mulai mendapat banyak kritik dikalangan Ilmuwan Komunikasi karena dirasakan memiliki banyak keterbatasan dan tidak dapat menjelaskan fenomena khas komunikasi yang ada di negaranegara di Asia. Muncul gerakan untuk mengembangkan teori komunikasi lokal (Indigineous Communication Theory) yang sesuai dengan masing-masing negara. Konsep utama yang dimunculkan sebagai benang pengikat adalah Teori Komunikasi Asia (Asian Communication Theory). Sayang Indonesia belum mengembangkan keberadaan Teori Komunikasi $\mathrm{Ke}$ Indonesiaan sebagai penciri khusus Indonesia di ranah keilmuan Komunikasi (Utari, 2012:444).

Para akademisi komunikasi kita cenderung terlena "menelan bulat-bulat" teori yang dibangun oleh ilmuan dari negara asing. Rasa percaya diri para akademisi kita belum terbangun dengan baik. Seolah konstruksi teori hanya boleh sebagai karya ilmuan ternama dari negeri orang. Para dosen pun tampaknya ikutikutan. Dalam memberikan kuliah, dosen langsung mengajar dari satu teori ke teori komunikasi yang lain kepada mahasiswa, tanpa atau sangat jarang menjelaskan proses, langkah dan komponen bangunan 
sebuahteorikomunikasi.Dibangkukuliah, pembahasan konstruksi teori hampir tidak tersentuh. Teori hanya dipelajari sebagai produk yang sudah "sempurna". Diperkuat lagi dengan gaya dosen seperti mendoktrin kebenaran sebuah teori. Dengan demikian bagi mahasiswa, teori komunikasi dipandang sebagai yang sulit, momok, dan menakutkan. Kondisi ini membuat mahasiswa seperti tak berdaya. Akibatnya, tidak banyak mahasiswa memiliki kemampuan mengkritisasi apalagi menyanggah sebuah teori. Teori komunikasi menjadi hafalan "mati" bagi mahasiswa. Realitas semacam ini kelak ke depan dapat mematikan kreativitas sarjana menghasilkan teori baru. Para ilmuan kita hanya sebagai user produk ilmuan lain (Emrus, 2012:354-355).

Teori dikonstruksikan melalui proses yang dikenal dengan inquiry. Untuk bisa memahami suatu teori maka diperlukan pemahaman awal terhadap proses inquiry. Inquiry adalah sebuah studi sistematis tentang pengalaman yang mengarah kepada pemahaman, pengetahuan dan teori. Proses inquiry mengikat orang ketika ia ingin memahami sesuatu secara tertata. Ada proses, tahapan dan metoda yang harus dilakukan untuk menghasilkan sebuah teori. Ketika melakukan proses inquiry ada tiga tahapan yang harus dilalui yaitu asking questions, observation dan constructing answers (Little jhon, 2008:7).

Gerald Miller dan Henry Nicholson percaya bahwa inquiry merupakan proses mengajukan pertanyaan yang menarik, signifikan dan memberikan jawaban yang sistematis terhadap pertanyaan-pertanyaan yang diajukan tersebut. Ada beberapa jenis pertanyaan yang sering diajukan yaitu, pertama, questions of definition yang merupakan upaya untuk mengklarifikasi apa yang diobservasi. Pertanyaan yang bisa diajukan diantaranya, apa yang kita observasi? Bagaimana kita menyebut/ menamai apa yang diobservasi?. Kedua adalah questions of fact, mempertanyakan properti dan relasi tentang apa yang diobservasi. Pertanyaan yang diajukan seperti terdiri dari apa saja obyek tersebut? bagaimana hubunganya dengan hal atau barang lain?. Ketiga, questions of value yang mempertanyakan tentang kualitas estetik, pragmatic dan etik dari apa yang diobservasi. Pertanyaan yang diajukan seperti, apakah ini indah?apakah ini efektif?apakah ini bagus? (Little John, 2008:7).

Secara umum teori menurut Littlejohn dan Foss (2008:14) adalah any organized sets of concepts, explanation and principles of some aspect of human experience. Serangkaian konsep-konsep, penjelasan-penjelasan serta prinsipprinsip yang dapat menjelaskan aspek tertentu dari pengalaman seseorang. Ada dua karakteristik teori yaitu abstraksi dan konstruksi. Abstraksi memperlihatkan teori itu hanya fokus pada sesuatu dan mengabaikan faktor-faktor lain. Untuk itu tidak ada suatu kebenaran yang absolut dalam suatu teori. Teori sesungguhnya hanya berfungsi untuk memahami, menjelaskan, menginterprestasi, menilai ataupun mengkomunikasikan suatu fenomena. Teori juga merupakan konstruksi (dibuat), diciptakan oleh manusia. Karena itu fokus suatu teori tergantung pada pembuat atau penciptanya. Bentukan suatu teori merupakan suatu cara melihat atau berfikir dari para pembuatnya (Utari, 2012:447).

Dalam perkembangannya, pemikiran teoritik komunikasi barat ini mulai dipertanyakan. Yoshitaka Miike (2002:1) melihat bahwa conventional academic views of communication have been skewed by Western frames of reference. They have no represented a sample of all possible conceptual positions from which the knowledge of communication can be constructed. Dengan kata lain bahwa 
pemikiran teoritik Komunikasi Barat ini memiliki berbagai keterbatasan (Utari, 2012:451).

Istilah teori komunikasi dapat merujuk pada teori tunggal, namun teori komunikasi dapat dipakai untuk memberi label pada kearifan kolektif (collective wisdom) yang ditemukan dalam keseluruhan wujud dari teoriteori yang berkaitan dengan komunikasi. McQuail (2000) dalam Rahardjo (2012, 561) menguraikan wujud nyata dari teori dan penelitian komunikasi dengan merumuskan pertanyaan-pertanyaan sebagai berikut:

1. Who communicate to whom? Siapa berkomunikasi dengan siapa? (sumber dan penerima).

2. Why communicate? Mengapa berkomunikasi (fungsi dan maksud/ tujuan).

3. How does communication take place? Bagaimana komunikasi berlangsung? (saluran, bahasa, kode).

4. What about? Tentang apa (isi, referensi, tipe informasi).

5. What are the outcomes of communication? Apa hasil dari komunikasi (disengaja atau tidak disengaja) terhadap informasi, pemahaman, tindakan?

McQuail (2010, 18) dalam Rahardjo (2012, 561-562) melengkapi pemikiran sebelumnya dengan menguraikan pertanyaan-pertanyaan untuk teori dan penelitian tentang jejaring dan proses komunikasi sebagai berikut:

1. Who is connected to whom in a given network and for what purpose?. Siapa terhubungkan dengan siapa dalam suatu jejaring dan untuk maksud apa?.

2. What is the pattern and direction of flow? Bagaimana pola dan arus komunikasinya?
3. How does communication take place? Bagaimana komunikasi berlangsung? (saluran, bahasa, kode).

4. What types of content are observed? Tipe-tipe isi apa yang diobservasi?.

5. What are the outcomes of communication? Apa hasil dari komunikasi, disengaja atau tidak disengaja.

Sumber perkembangan teori komunikasi terbuka luas dari beragam disiplin ilmu termasuk di dalamnya kajian dari kitab suci agama dan kearifan pemikiran lokal yang ada di setiap suku bangsa. Teori komunikasi sebagai bahan kajian dan implementasi teori dalam praksis tidak terlepas dari pengaruh kearifan lokal yang ada di setiap suku bangsa. Demikian halnya dengan pengaruh kitab suci agama yang dianut oleh setiap individu yang terlibat dalam proses komunikasi.

Kitab suci agama adalah sumber pedoman bertingkah dan berperilaku dalam kehidupan sehari-hari. Tata nilai yang terkandung dalam kitab suci sarat dengan nilai-nilai moral dan spiritual yang menjadi pembeda dalam rujukan keilmuan. Salah satu kitab suci yang menjadi acuan kehidupan manusia adalah AL Qur'an sebagai pedoman hidup umat Islam.

Islam adalah agama samawi yang dianut oleh jutaan manusia di dunia. Penyebaran umat Islam di dunia dengan sendirinya merepresentasikan penyebaran implementasi nilai-nilai AL Qur' an dalam kehidupan manusia di berbagai penjuru dunia. Nilai-nilai tersebut menjadi pedoman dalam bertingkahlaku di semua aspek kehidupan manusia. Kegiatan berkomunikasi yang dilakukan oleh umat Islam dengan sendirinya juga tidak lepas dari tuntunan yang ada dalam kitab suci tersebut.

Al Qur'an adalah kitab suci yang terjaga keotentikannya sehingga 
isi yang terkandung di dalamnya sama dari awal diturunkannya. Al Qur'an turun kepada Rasulullah Muhammad SAW semenjak empat belas abad yang lampau dan sampai hari ini tetap terjaga keotentikannya. Jaminan akan otentisitas tersebut berasal dari Alloh SWT yang berfirman: "Sesungguhnya Kami yang telah menurunkan AL Qur'an dan sesungguhnya Kami pula yang akan menjaganya (Q.S Al Hijr:15)"

Kandungan AL Qur'an secara garis besar terbagi dalam tiga hal:

1. Akidah

Aqidah adalah ilmu yang mengajarkan manusia mengenai kepercayaan yang wajib dimiliki oleh seorang muslim.

2. Ibadah

Ibadah adalah taat, tunduk, terhadap syariat ibadah yang telah ditentukan dalam syariat Islam. Dalam pandangan para ahli fikih, ibadah didefinisikan sebagai segala bentuk ketaatan yang dijalankan untuk mendapatkan ridho Alloh SWT.

3. Muamalah

Muamalah mengatur hubungan antarmanusia dalam beberapa ikatan seperti ekonomi, perdagangan, akhlak, dan hubungan lain yang bersifat perseorangan dan kelompok.

4. Sejarah/kisah-kisah

Sejarah dari umat-umat terdahulu diceritakan dalam Al Qur'an untuk memberikan pelajaran bagi manusia. Beragam kisah tersebut merupakan pedoman berbuat dan berperilaku bagi umat yang mau mengambil pelajaran.

5. Hukum

Hukum dalam Al Qur'an mengatur segala aspek terkait hubungan manusia dengan Rab, manusia dengan sesamanya, dengan lingkungan, binatang yang terkait dengan aspek hukum.
Isi Al Qur'an yang menjadi pedoman bagijutaan umat di seluruh dunia merupakan sumber dari beragam ilmu pengetahuan manusia. Ilmu komunikasi sebagai salah satu cabang ilmu yang berkembang dengan beragam sumber juga tidak lepas dari pembahasan dalam AL Qur'an. Kitab yang bersumber dari wahyu ilahi merupakan kesempurnaan yang dijamin dan terjaga dari waktu ke waktu.

Kandungan Al Qur'an berisi ayat-ayat muhkamat dan mutasabihat. Ayat muhkamat merupakan ayat yang sudah jelas maksudnya sehingga tidak membutuhkan tafsir atau penjelasan lebih lanjut. Contoh dari ayat muhkamat diantaranya adalah perintah untuk melaksanakan puasa, berhaji, berzakat dan perintah lain yang tidak menimbulkan multitafsir. Beberapa ayat lain yang bersifat mutasabihat membutuhkan penafsiran yang didasarkan oleh beberapa rujukan. Beberapa metode tafsir AL Qur'an yaitu menafsirkan ayat satu dengan ayat lain, menafsirkan ayat dengan hadist yang shohih, pendapat sahabat, dan menafsirkan ayat dengan bahasa arab.

Tafsir Al Qur'an sebagai buah dari usaha penulisnya untuk menjelaskan setiap ayat merupakan bagian dari dinamika perkembangan ilmu. Beberapa masalah kontemporer membutuhkan penjelasan landasan hukumnya berbadasar Al Qur'an. Kajian-kajian tersebut tidak berarti menunjukkan adanya kekurangan dlam isi Al Qur'an namun justru menunjukkan kesempurnaan isinya yang tetap relevan dengan perkembangan manusia.

Salah satu surat dalam Al Qur'an yang merupakan bagian inti dari kitab tersebut adalah surat Al Fatihah. Surat ini sering disebut sebagai umul kitab yang menunjukkan kandungan isinya. AL Fatihah dibaca oleh setiap muslim setiap kali mereka melaksanakan sholat. Oleh 
karena itu kandungan di dalam surat ini memberikan efek besar bagi kehidupan manusia dalam berbagai aspek. Teori komunikasi yang merupakan ilmu terbuka dengan beragam sumber rujukan tidak menafikan untuk membangun rekonstruksi ilmu berdasar kandungan surat ini. Oleh karena itu menarik untuk diteliti kandungan dan konstruksi teori komunikasi dalam surat ini.

\section{B. Asbabun Nuzul Surat Al Fatihah}

Al-Qur'an adalah merupakan kalamullah (firman Allah) yang mengandung mukjizat, yang diturunkan kepada Nabi dan Rasul terakhir, dengan perantaraan Al-Amin Jibril as. Yang tertulis dalam mushaf, yang disampaikan kepada kita secara mutawatir yang dianggap sebagai ibadah membacanya, yang dimulai dengan surat Al-Fatihah dan ditutup dengan surat An-Nas. Al-Qur'an sebagaimana dimaksud dalam definisi tersebut adalah merupakan pedoman utama ummat Islam dalam hidup dan kehidupannya sehari-hari baik dalam hal ibadah maupun dalam hal mu'amalah. Untuk itu maka Al-Qur'an perlu dikaji, dipelajari dan dihayati sehingga isi kandungan Al-Qur'an tersebut dapat dipedomani dan dilaksanakan serta dapat dijadikan petunjuk bagi ummat manusia dalam hidup dan kehidupan sehari-hari.

Mengingat bahwa Al-Qur'an adalah merupakan firman Allah SWT maka tidak seorangpun yang dapat memahaminya secara utuh dan benar sebagaimana yang dimaksud oleh Allah SWT, keculai Nabi Muhammad SAW sebab beliau yang menerima, dan beliau pula yang diperintahkan untuk menyampaiklannya kepada ummat manusia. Dan apabila beliau kurang memahami Al-Qur'an yang diturunkan kepadaNya maka beliau secara langsung dapat meminta penjelasan kepada Malaikat Jibril as. Berbeda halnya dengan kita yang tidak dapat lagi meminta penjelasan secara langsung kepada Nabi Muhammad SAW apalagi kepada Malaikat Jibril.

Untuk itu maka diperlukan ilmuilmu bantu yang berkaitan dengan AlQur'an seperti penguasaan terhadap Bahasa dan Sastra Arab, Ilmu Nahwu, Ilmu Sharaf, Ilmu Mantihiq, Ilmu Balaghah, Kondisi sosiologis tempat turunnya Al-Qur'an, Ilmu Ushul Fiqh apabila hal itu berkaitan dengan bidang hukum, Pengetahuan tentang Asbabun Nuzul dan lain-lain sebagainya. Dalam kaitan dengan pembahasan makalah ini maka yang akan dibicarakan secara panjang lebar adalah tentang Asbabun Nuzul kaitannya dengan memahami isi kandingan Al-Qur'an, sebab Asbabun Nuzul sebagaimana disebutkan oleh Ibnu Taimiyah, "mengetahui alasan (sabab) penurunan membantu dalam memahami ayat, karena pengetahuan tentang sebab (sabab) menghasilkan pengetahuan tentang efek (musabbab) ${ }^{7}$.

Asbabun Nuzul secara bahasa berarti sebab turunnya ayat-ayat AlQur'an. Sebagaimana diketahui bahwa Al-Qur'an diturunkan Allah SWT selama masa 22 tahun 2 bulan dan 22 hari atau lebih kurang 23 tahun. AlQur'an diturunkan oleh Allah SWT pada dasarnya adalah untuk memperbaiki aqidah, ibadah, akhlak dan pergaulan manusia yang telah menyimpang dari rel kebenaran. Oleh karena itu secara bahasa sebenarnya penyebab turunnya Al-Qur'an adalah karena kerusakan dan penyimpangan aqidah, ibadah, akhlak dan tata pergaulan ummat manusia. Namun demikian bukanlah ini yang dimaksud dalam pembahasan makalah ini, sebab ini adalah sifatnya umum.

Adapun pengertian Asbabun Nuzul secara Ishtilahi sebagaimana

7 Drs. H. Ahmad Supardi Hasibuan, MA, PERANAN ASBABUN NUZUL DALAM MEMAHAMI AL-QUR'AN, http://riau.kemenag.go.id/index.php?a=artikel\&id=10114 
disebutkan oleh Shubhi Al-Shalih dalam bukunya Mabahits Fi 'Ulumil Qur'an adalah sesuatu yang dengan sebabnya turun suatu ayat atau beberapa ayat yang mengandung sebab itu, atau memberi jawaban terhadap sebab itu, atau menerangkan hukumnya pada masa terjadinya sebab tersebut.

Definisi yang dikemukakan oleh Shubhis Shalih tersebut memberikan pengertian bahwa sebab turun ayat adakalanya berbentuk peristiwa dan adakalanya berbentuk pertanyaan. Oleh karena itulah maka setiap turun suatu ayat atau beberapa ayat, hal itu adalah untuk menerangkan hal-hal yang berhubungan dengan peristiwa atau sebagai jawaban atas suatu pertanyaan yang diajukan kepada Nabi Muhammad SAW. Namun demikian tidak semua ayat Al-Qur'an itu turun dengan adanya Asbabun Nuzul, sebab banyak juga ayat-ayat Al-Qur'an yang turun tanpa sebab dan bahkan banyak ayat-ayat yang berkaitan dengan keimanan, kewajiban, syari'at agama dan kissah para Nabi dan Rasul terdahulu turun tanpa sebab.

Memang harus diakui bahwa ada sebagian sahabatsepertiAliIbnAbiThalib, Ibn Mas'ud dan lainnya yang menyatakan bahwa tidak suatu ayatpun diturunkan kecuali salah seorang mereka mengetahui tentang apa ayat itu diturunkan, tentang siapa ayat itu diturunkan, dan dimana ayat itu diturunkan. Pernyataan ini tidak perlu ditanggapi secara leterlek sebab merupakan suatu hal yang masuk akal bahwa tidak semua Asbabun Nuzul ayat Al-Qur'an itu mereka saksikan. Untuk itu pernyataan mereka itu harus dipahami melalui beberapa kemungkinan, yaitu :

1. Mereka bermaksud mengungkapkan betapa kuatnya perhatian mereka terhadap Al-

2. Qur'an dan mengikuti setiap keadaan yang berhubungan dengannya.

3. Mereka berbaik sangka dengan segala apa yang mereka dengar dan saksikan pada masa Rasul dan menginginkan agar orang mengambil apa yang mereka ketahui itu sehingga tidak akan lenyap dengan berakhirnya hidup mereka.

4. Para periwayat menambah dalam periwayatannya dan membangsakannya kepada sahabat.

Drs. H. Ramli Abdul Wahid, MA dalam bukunya Ulumul Qur'an menyebutkan bahwa sebab-sebab turun ayat yang berhubungan dengan peristiwa ada tiga macam dan yang berhubungan dengan pertanyaan juga ada tiga macam. Adapun sebab-sebab turun ayat yang berhubungan dengan pertanyaan adalah sebagai berikut :

1. Peristiwa berupa pertengkaran, seperti perselisihan yang berkecamuk antara segolongan dari suku Aus dan segolongan dari suku Khazraj. Perselisihan itu timbul dari intrikintrik yang ditiupkan orang-orang Yahudi sehingga mereka berteriakteriak : "Senjata, senjata", maka turunlah Al-Qur'an Surat Ali Imran ayat 100 .

2. Peristiwa berupa kesalahan yang serius, seperti peristiwa seorang yang mengimami sholat sedang mabuk sehingga tersalah membaca surah Al-Kafirun, sehingga turunlah Al-Qur'an surat Al-Nisa' ayat 42. Peristiwa itu berupa cita-cita dan keinginan, seperti persesuaianpersesuaian (muwafaqat) Umar Ibn Al-Khaththab dengan ketentuan ayat-ayat Al-Qur'an. Dalam sejarah, ada beberapa harapan Umar yang dikemukakannya kepada Nabi Muhammad SAW, kemudian turunlah ayat yang sesuai dengan harapanharapan Umar tersebut. Sebagai contoh adalah keinginan Umar Ibn Khaththab untuk menjadikan Makam Ibrahim sebagai tempat shalat, maka turunlah ayat yang memerintahkan 
untuk melaksanakan sholat di Makam Ibrahim.

Adapun sebab-sebab turun ayat yang berkaitan dalam bentuk pertanyaan adalah terbagi tiga macam, yaitu :

1. Pertanyaan yang berhubungan dengan sesuatu yang telah lalu, seperti ayat pertanyaan tentang Zul Karnain, "Mereka bertanya kepadamu tentang Zul Karnain".

2. Pertanyaan yang berhubungan dengan sesuatu yang sedang berlangsung pada waktu itu, seperti pertanyaan tentang ruh, "Dan mereka bertanya kepadamu tentang ruh, katakanlah bahwa urusan ruh itu adalah urusan Tuhanku, dan kamu tidak diberi ilmu kecuali yang sedikit".

3. Pertaanyaan yang berhubunagn dengan masa yang akan datang, seperti pertanyaan tentang kapan terjadinya Hari Kiamat, "Mereka bertanya kepadamu tentang Hari Kiamat, Bila terjadinya ?".

Surat Al-Fatihah yang merupakan surat pertama dalam Al Qur'an dan terdiri dari 7 ayat adalah masuk kelompok surat Makkiyyah, yakni surat yang diturunkan saat Nabi Muhammad di kota Mekah. Dinamakan Al-Fatihah, lantaran letaknya berada pada urutan pertama dari 114 surat dalam Al Qur'an. Para ulama bersepakat bahwa surat yang diturunkan lengkap ini merupakan intisari dari seluruh kandungan Al Qur'an yang kemudian dirinci oleh surat-surat sesudahnya. Surat Al-Fatihah adalah surat Makkiyyah, yaitu surat yang diturunkan di Mekkah sebelum Rasulullah SAW hijrah ke Madinah. Surat ini berada di urutan pertama dari surat-surat dalam Al-Qur'an dan terdiri dari tujuh ayat. Tema-tema besar Al Qur'an seperti masalah tauhid, keimanan, janji dan kabar gembira bagi orang beriman, ancaman dan peringatan bagi orang-orang kafir serta pelaku kejahatan, tentang ibadah, kisah orang- orang yang beruntung karena taat kepada Allah dan sengsara karena mengingkariNya, semua itu tercermin dalam ekstrak surat Al Fatihah ${ }^{8}$.

Surat Al Fatihah memiliki banyak nama. Di antaranya; Fatihatul Kitab (pembuka kitab/Al Qur'an). Karena Al Qur'an, secara penulisan dibuka dengan surat ini. Demikian pula dalam shalat, Al Fatihah sebagai pembuka dari surat-surat lainnya. Al Fatihah dikenal juga dengan sebutan As Sab'ul Matsani (tujuh yang diulang-ulang). Disebabkan surat ini dibaca berulang-ulang pada setiap raka' at dalam shalat. Dinamakan juga dengan Ummul Kitab. Karena di dalamnya mencakup pokok-pokokAlQur'an, seperti aqidah dan ibadah. Menurut al-Qurtubhi surat al-Fatihah memiliki 12 nama, yakni al-salah (salat, doa), fatihatul kitab (induk alkitab), ummul kitab (induk al-Quran), al-matsani (berulang-ulang), al-quranul 'azhim (al-Quran yang agung), asy-syifa (penawar, obat, penyembuh), ar-ruqyah (rukyah), al-asas (fondasi), al-wafiyah (yang menyeluruh, komprehensif), alkafiyah (yang sempurna) dan al-fatihah (pembuka) ${ }^{9}$.

Dari Abu Hurairah Radhiallahu Anhu berkata : telah bersabda Rasulullah SAW : Al-Hamdulillah (Al-Fatihah) adalah Ummul Qur'an, Ummul Kitab, As-Sabul Matsaani dan Al-Qur'anul Adhim. (HR. At-Tirmidzi dengan sanad sahih). Dinamakan dengan Ummul Kitab atau Umul Qur'an, yaitu induk AlQur'an, karena di dalamnya mencakup inti ajaran Al-Quran.

\section{Keutamaan Surat Al Fatihah}

\section{Membaca Al-Fatihah Adalah Rukun Shalat}

Nabi shallallahu 'alaihi wa sallam bersabda yang artinya, "Tidak ada

\footnotetext{
8 http://www.elfawaz.com/

9 http://belajar-islamic.blogspot.com/2011/07/

asbabun-nuzul-sebab-sebab-turunnya.html
} 
shalat bagi orang yang tidak membaca Fatihatul Kitab (Al Fatihah)." (HR. Bukhari dan Muslim dari Ubadah bin Shamit radhiyallahu 'anhu). Dalam sabda yang lain beliau mengatakan yang artinya, "Barangsiapa yang shalat tidak membaca Ummul Qur'an (surat Al Fatihah) maka shalatnya pincang (khidaaj)." (HR. Muslim). Makna dari khidaaj adalah kurang, sebagaimana dijelaskan dalam hadits tersebut, "Tidak lengkap". Berdasarkan hadits ini dan hadits sebelumnya para imam seperti imam Malik, Syafi'i, Ahmad bin Hanbal dan para sahabatnya, serta mayoritas ulama berpendapat bahwa hukum membaca Al Fatihah di dalam shalat adalah wajib, tidak sah shalat tanpanya.

\section{Al Fatihah Adalah Surat Paling Agung Dalam Al Quran}

Dari Abu Sa'id Rafi' Ibnul Mu'alla radhiyallahu 'anhu, beliau mengatakan: Rasulullah shallallahu 'alaihi wa sallam berkata kepadaku, "Maukah kamu aku ajari sebuah surat paling agung dalam Al Quran sebelum kamu keluar dari masjid nanti?" Maka beliaupunberjalansembarimenggandeng tanganku. Tatkala kami sudah hampir keluar maka aku pun berkata; Wahai Rasulullah, Anda tadi telah bersabda, "Aku akan mengajarimu sebuah surat paling agung dalam Al Quran?” Maka beliau bersabda, "(surat itu adalah) Alhamdulillaahi Rabbil alamiin (surat Al Fatihah), itulah As Sab'ul Matsaani (tujuh ayat yang sering diulang-ulang dalam shalat) serta Al Quran Al 'Azhim yang dikaruniakan kepadaku." (HR. Bukhari, dinukil dari Riyadhush Shalihin cet. Darus Salam, hal. 270).

Dari Abu Sa'id Rafi' Ibnul Mu'alla radhiyallahu 'anhu, beliau mengatakan: Rasulullah shallallahu 'alaihi wa sallam berkata kepadaku, "Maukah kamu aku ajari sebuah surat paling agung dalam Al Quran sebelum kamu keluar dari masjid nanti?" Maka beliau pun berjalan sembari menggandeng tanganku. Tatkala kami sudah hampir keluar maka aku pun berkata; Wahai Rasulullah, Anda tadi telah bersabda, "Aku akan mengajarimu sebuah surat paling agung dalam Al Quran?" Maka beliau bersabda, "(surat itu adalah) Alhamdulillaahi Rabbil 'alamiin (surat Al Fatihah), itulah As Sab'ul Matsaani (tujuh ayat yang sering diulang-ulang dalam shalat) serta Al Quran Al 'Azhim yang dikaruniakan kepadaku." (HR. Bukhari, dinukil dari Riyadhush Shalihin cet. Darus Salam, hal. 270)

Al-Fatihah adalah surat yang paling utama. Dari Anas bin Malik ra. berkata: Tatkala Nabi saw dalam sebuah perjalanan lalu turun dari kendaraannya, turun pula seorang lelaki di samping beliau. Lalu Nabi menoleh ke arah lelaki tersebut kemudian berkata: "Maukah kamu aku beritahukan surat yang paling utama di dalam al-Quran? Anas berkata: Kemudian Nabi saw membacakan ayat 'segala puji bagi Allah Tuhan semesta alam.'

Al-Fatihah dapat digunakan untuk meruqyah. Dari Abi Sa'id alKhudry dan Abu Hurairah ra (keduanya) berkata: "Rosulullah saw bersabda, surat pembuka al-Kitab dapat menyembuhkan dan menawarkan racun." Mengucapkan amin akan menghapus dosa-dosa. Dari Abu Hurairah RA., Sesungguhnya Nabi SAW bersabda: "Jika imam mengucapkan 'ghoiril magdhubi 'alaihim waladh dhallin', maka sambutlah dengan ucapan 'amin', karena para malaikatpun mengucapkan 'amin' dan sesungguhnya imampun mengucapkan 'amin' pula. Maka barang siapa yang ucapan 'amin'nya sesuai dengan ucapan malaikat, akan diampuni dosa-dosanya yang terdahulu.

Allah tidak pernah menurunkan dalam Taurat dan Injil yang seperti surat Al-Fatihah. (HR. At-Tirmidzi dengan sanad sahih). Al-Fatihah adalah Ruqyah, yaitu jampi-jampi untuk mengobati 
penyakit. (HR. Bukhari). Shalat tidak sah tanpa membaca Al-Fatihah. (HR. Muslim dan An-Nasa'i). Al-Fatihah adalah dialog hamba dengan Allah Taa'la. (HR. Muslim danAn-Nasa?i). Dari Abu Hurairah r.a dari Rasulullah SAW bersabda: Barangsiapa shalat yang tidak membaca di dalamnya Ummul Qur'an (Al-Fatihah) maka shalatnya tidak sempurna (Rasulullah SAW mengulanginya tiga kali).

Lalu ditanyakan kepada Abu Hurairah r.a : Bagaimana apabila kita dibelakang imam. Abu Hurairah r.a menjawab: Bacalah (Al-Fatihah) dalam dirimu, karena sesungguhnya aku pernah mendengar Rasulullah SAW bersabda: Allah Azza wa Jalla berfirman: Aku membagi shalat (Al-Fatihah) antara Aku dengan hambaKu menjadi dua bagian dan bagi hambaKu apa yang dia minta.

Apabila dia (hamba) mengucapkan: Segala puji hanya bagi Allah, Tuhan sekalian alam. Allah Taa'la menjawab: Hambaku memujiKu. Dan apabila dia (hamba) mengucapkan: Maha Pemurah lagi Maha Penyayang. Allah Taa'la menjawab: HambaKu menyanjung-nyanjungKu. Dan apabila dia (hamba) mengucapkan: Yang menguasai hari pembalasan. Allah Taa'la menjawab: HambaKu mengagungagungkanKu. Dan apabila dia (hamba) mengucapkan: Hanya kepada Engkaulah kami menyembah dan hanya kepada Engkaulah kami mohon pertolongan. Allah Taa'la menjawab: Ini adalah antara Aku dengan hambaKu dan bagi hambaKu apa yang dia minta. Dan apabila dia (hamba) mengucapkan: Tunjukilah kami jalan yang lurus, (yaitu) jalan orangorang yang telah Engkau anugerahkan nikmat kepada mereka; bukan jalan mereka yang dimurkai dan bukan pula jalan mereka yang sesat. Allah Taa'la menjawab: Ini adalah untuk hambaKu dan bagi hambaKu apa yang dia minta. (HR. Muslim dan An-Nasai).
Penjelasan Kandungan Surat

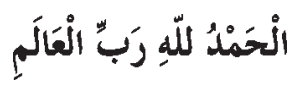

Artinya: "Segala puji bagi Allah Rabb seru sekalian alam."

Makna Alhamdu adalah pujian kepada Allah karena sifat-sifat kesempurnaan-Nya. Dan juga karena perbuatan-perbuatanNya yang tidak pernah lepas darisifat memberikan karunia atau menegakkan keadilan. Perbuatan Allah senantiasa mengandung hikmah yang sempurna. Pujian yang diberikan oleh seorang hamba akan semakin bertambah sempurna apabila diiringi dengan rasa cinta dan ketundukkan dalam dirinya kepada Allah. Karena pujian semata yang tidak disertai dengan rasa cinta dan ketundukkan bukanlah pujian yang sempurna.

Makna dari kata Rabb adalah Murabbi (yang mentarbiyah; pembimbing dan pemelihara). Allahlah Zat yang memelihara seluruh alam dengan berbagai macam bentuk tarbiyah. Allahlah yang menciptakan mereka, memberikan rezeki kepada mereka, memberikan nikmat kepada mereka, baik nikmat lahir maupun batin. Inilah bentuk tarbiyah umum yang meliputi seluruh makhluk, yang baik maupun yang jahat. Adapun tarbiyah yang khusus hanya diberikan Allah kepada para Nabi dan pengikutpengikut mereka. Di samping tarbiyah yang umum itu Allah juga memberikan kepada mereka tarbiyah yang khusus yaitu dengan membimbing keimanan mereka dan menyempurnakannya. Selain itu, Allah juga menolong mereka dengan menyingkirkan segala macam penghalang dan rintangan yang akan menjauhkan mereka dari kebaikan dan kebahagiaan mereka yang abadi. Allah memberikan kepada mereka berbagai kemudahan dan menjaga mereka dari hal-hal yang dibenci oleh syariat.

Dari sini kita mengetahui betapa 
besar kebutuhan alam semesta ini kepada Rabbul 'alamiin karena hanya Dialah yang menguasai itu semua. Allah satusatunya pengatur, pemberi hidayah dan Allah lah Yang Maha kaya. Oleh sebab itu semua makhluk yang ada di langit dan di bumi ini meminta kepada-Nya. Mereka semua meminta kepada-Nya, baik dengan ucapan lisannya maupun dengan ekspresi dirinya. Kepada-Nya lah mereka mengadu dan meminta tolong di saat-saat genting yang mereka alami (lihat Taisir Lathiifil Mannaan, hal. 20).

Makna ayat kedua

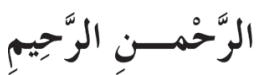

Artinya: "Yang Maha Pemurah lagi Maha Penyayang."

Ar-Rahman dan Ar-Rahiim adalah nama Allah. Sebagaimana diyakini oleh Ahlusunnah wal Jama'ah bahwa Allah memiliki nama-nama yang terindah. Allah ta'ala berfirman,

"Milik Allah nama-nama yang terindah, maka berdo'alah kepada Allah dengan menyebutnya." (QS. Al A'raaf: 180)

Setiap nama Allah mengandung sifat. Oleh sebab itu beriman kepada nama-nama dan sifat-sifat Allah merupakan bagian yang tak terpisahkan dari keimanan kepada Allah. Dalam mengimani nama-nama dan sifat-sifat Allah ini kaum muslimin terbagi menjadi 3 golongan yaitu: (1) Musyabbihah, (2) Mu'aththilah dan (3) Ahlusunnah wal Jama'ah. Musyabbihah adalah orangorang yang menyerupakan sifat-sifat Allah dengan sifat makhluk. Mereka terlalu mengedepankan sisi penetapan nama dan sifat dan mengabaikan sisi penafian keserupaan sehingga terjerumus dalam tasybih (peyerupaan). Adapun Mu'aththilah adalah orang-orang yang menolak nama atau sifat-sifat Allah. Mereka terlalu mengedepankan sisi penafian sehingga terjerumus dalam ta'thil (penolakan). Ahlusunnah berada di tengah-tengah. Mereka mengimani dalil-dalil yang menetapkan nama dan sifat sekaligus mengimani dalil-dalil yang menafikan keserupaan. Sehingga mereka selamat dari tindakan tasybih maupun ta'thil. Oleh sebab itu mereka menyucikan Allah tanpa menolak nama maupun sifat. Mereka menetapkan nama dan sifat tapi tanpa menyerupakannya dengan makhluk. Inilah akidah yang dipegang oleh Rasulullah shallallahu 'alaihi wa sallam dan para sahabatnya serta para imam dan pengikut mereka yang setia hingga hari ini. Inilah aqidah yang tersimpan dalam ayat yang mulia yang artinya,

"Tidak ada sesuatupun yang serupa dengan-Nya, dan Dia Maha Mendengar lagi Maha Melihat.” (QS. Asy Syuura: 11) (silakan baca $\mathrm{Al}$ 'Aqidah $\mathrm{Al}$ Wasithiyah karya Syaikhul Islam Ibnu Taimiyah dan juga 'Aqidah Ahlis Sunnah wal Jama'ah karya Syaikh Ibnu Utsaimin rahimahumallahu ta'ala).

Allah Maha Mendengar dan juga Maha Melihat. Akan tetapi pendengaran dan penglihatan Allah tidak sama dengan pendengaran dan penglihatan makhluk. Meskipun namanya sama akan tetapi hakikatnya berbeda. Karena Allah adalah Zat Yang Maha Sempurna sedangkan makhluk adalah sosok yang penuh dengan kekurangan. Sebagaimana sifat makhluk itu terbatas dan penuh kekurangan karena disandarkan kepada diri makhluk yang diliputi sifat kekurangan. Maka demikian pula sifat Allah itu sempurna karena disandarkan kepada sosok yang sempurna. Sehingga orang yang tidak mau mengimani kandungan hakiki nama-nama dan sifat-sifat Allah sebenarnya telah berani melecehkan dan berbuat lancang kepada Allah. Mereka tidak mengagungkan Allah dengan sebagaimana semestinya. Lalu adakah tindakan jahat yang lebih tercela daripada tindakan menolak kandungan nama dan sifat Allah ataupun menyerupakannya 
dengan makhluk? Di dalam ayat ini Allah menamai diri-Nya dengan Ar-Rahman dan Ar-Rahiim. Di dalamnya terkandung sifat Rahmah (kasih sayang). Akan tetapi kasih sayang Allah tidak serupa persis dengan kasih sayang makhluk.

Makna ayat ketiga

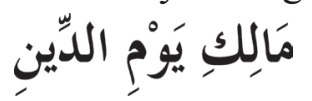

Artinya: "Yang Menguasai pada hari pembalasan."

Maalik adalah zat yang memiliki kekuasaan atau penguasa. Penguasa itu berhak untuk memerintah dan melarang orang-orang yang berada di bawah kekuasaannya. Dia juga yang berhak untuk mengganjar pahala dan menjatuhkan hukuman kepada mereka. Dialah yang berkuasa untuk mengatur segala sesuatu yang berada di bawah kekuasaannya menurut kehendaknya sendiri. Bagian awal ayat ini boleh dibaca Maalik (dengan memanjangkan mim) atau Malik (dengan memendekkan mim). Maalik maknanya penguasa atau pemilik. Sedangkan Malik maknanya raja.

Yaumid diin adalah hari kiamat. Disebut sebagai hari pembalasan karena pada saat itu seluruh umat manusia akan menerimabalasanamalbaikmaupunburuk yang mereka kerjakan sewaktu di dunia. Pada hari itulah tampak dengan sangat jelas bagi manusia kemahakuasaan Allah terhadap seluruh makhluk-Nya. Pada saat itu akan tampak sekali kesempurnaan dari sifat adil dan hikmah yang dimiliki Allah. Pada saat itu seluruh raja dan penguasa yang dahulunya berkuasa di alam dunia sudah turun dari jabatannya. Hanya tinggal Allah sajalah yang berkuasa. Pada saat itu semuanya setara, baik rakyat maupun rajanya, budak maupun orang merdeka. Mereka semua tunduk di bawah kemuliaan dan kebesaran-Nya. Mereka semua menantikan pembalasan yang akan diberikan oleh-Nya. Mereka sangat mengharapkan pahala kebaikan dari-Nya.
Dan mereka sungguh sangat khawatir terhadap siksa dan hukuman yang akan dijatuhkan oleh-Nya. Oleh karena itu di dalam ayat ini hari pembalasan itu disebutkan secara khusus. Allah adalah penguasa hari pembalasan. Meskipun sebenarnya Allah jugalah penguasa atas seluruh hari yang ada. Allah tidak hanya berkuasa atas hari kiamat atau hari pembalasan saja (lihat Taisir Karimir Rahman, hal. 39).

Makna ayat keempat

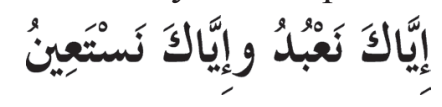

Artinya: "Hanya kepada-Mu lah Kami beribadah dan hanya kepada-Mu lah Kami meminta pertolongan."

Maknanya: "Kami hanya menujukan ibadah dan isti'anah (permintaan tolong) kepada-Mu." Di dalam ayat ini objek kalimat yaitu Iyyaaka diletakkan di depan. Padahal asalnya adalah na'buduka yang artinya Kami menyembah-Mu. Dengan mendahulukan objek kalimat yang seharusnya di belakang menunjukkan adanya pembatasan dan pengkhususan. Artinya ibadah hanya boleh ditujukan kepada Allah. Tidak boleh menujukan ibadah kepada selain-Nya. Sehingga makna dari ayat ini adalah, 'Kami menyembah-Mu dan kami tidak menyembah selain-Mu. Kami meminta tolong kepada-Mu dan kami tidak meminta tolong kepada selain-Mu.

Ibadah adalah segala sesuatu yang dicintai dan diridhai oleh Allah. Ibadah bisa berupa perkataan maupun perbuatan. Ibadah itu ada yang tampak dan ada juga yang tersembunyi. Kecintaan dan ridha Allah terhadap sesuatu bisa dilihat dari perintah dan larangan-Nya. Apabila Allah memerintahkan sesuatu maka sesuatu itu dicintai dan diridai-Nya. Dan sebaliknya, apabila Allah melarang sesuatu maka itu berarti Allah tidak cinta dan tidak ridha kepadanya. Dengan demikian ibadah itu luas cakupannya. Di antara bentuk ibadah 
adalah do'a, berkurban, bersedekah, meminta pertolongan atau perlindungan, dan lain sebagainya. Dari pengertian ini maka isti' anah atau meminta pertolongan juga termasuk cakupan dari istilah ibadah. Lalu apakah alasan atau hikmah di balik penyebutan kata isti'anah sesudah disebutkannya kata ibadah di dalam ayat ini?

$$
\text { Syaikh Abdurrahman bin }
$$
Nashir As-Sa'di rahimahulah berkata, "Didahulukannya ibadah sebelum isti' anah ini termasuk metode penyebutan sesuatu yang lebih umum sebelum sesuatu yang lebih khusus. Dan juga dalam rangka lebih mengutamakan hak Allah ta'ala di atas hak hamba-Nya"

\section{Beliau pun berkata, "Mewujudkan} ibadah dan isti'anah kepada Allah dengan benar itu merupakan sarana yang akan mengantarkan menuju kebahagiaan yang abadi. Dia adalah sarana menuju keselamatan dari segala bentuk kejelekan. Sehingga tidak ada jalan menuju keselamatan kecuali dengan perantara kedua hal ini. Dan ibadah hanya dianggap benar apabila bersumber dari Rasulullah shallallahu 'alaihi wa sallam dan ditujukan hanya untuk mengharapkan wajah Allah (ikhlas). Dengan dua perkara inilah sesuatu bisa dinamakan ibadah. Sedangkan penyebutan kata isti'anah setelah kata ibadah padahal isti'anah itu juga bagian dari ibadah maka sebabnya adalah karena hamba begitu membutuhkan pertolongan dari Allah ta'ala di dalam melaksanakan seluruh ibadahnya. Seandainya dia tidak mendapatkan pertolongan dari Allah maka keinginannya untuk melakukan perkara-perkara yang diperintahkan dan menjauhi hal-hal yang dilarang itu tentu tidak akan bisa tercapai." (Taisir Karimir Rahman, hal. 39).

Makna ayat kelima

Artinya: "Tunjukilah Kami jalan yang lurus."
Maknanya:

"Tunjukilah, bimbinglah dan berikanlah taufik kepada kami untuk meniti shirathal mustaqiim yaitu jalan yang lurus." Jalan lurus itu adalah jalan yang terang dan jelas serta mengantarkan orang yang berjalan di atasnya untuk sampai kepada Allah dan berhasil menggapai surga-Nya. Hakikat jalan lurus (shirathal mustaqiim) adalah memahami kebenaran dan mengamalkannya. Oleh karena itu ya Allah, tunjukilah kami menuju jalan tersebut dan ketika kami berjalan di atasnya. Yang dimaksud dengan hidayah menuju jalan lurus yaitu hidayah supaya bisa memeluk erat-erat agama Islam dan meninggalkan seluruh agama yang lainnya. Adapun hidayah di atas jalan lurus ialah hidayah untuk bisa memahami dan mengamalkan rincian-rincian ajaran Islam. Dengan begitu do'a ini merupakan salah satu do'a yang paling lengkap dan merangkum berbagai macam kebaikan dan manfaat bagi diri seorang hamba. Oleh sebab itulah setiap insan wajib memanjatkan do'a ini di dalam setiap rakaat shalat yang dilakukannya. Tidak lain dan tidak bukan karena memang hamba begitu membutuhkan do'a ini (lihat Taisir Karimir Rahman, hal. 39).

Makna ayat keenam

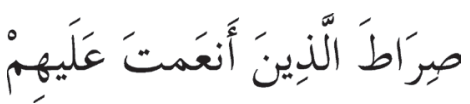

Artinya: "Yaitu jalannya orang-orang yang Engkau berikan nikmat atas mereka."

Siapakah orang-orang yang diberi nikmat oleh Allah? Di dalam ayat yang lain disebutkan bahwa mereka ini adalah para Nabi, orang-orang yang shiddiq/jujur dan benar, para pejuang Islam yang mati syahid dan orang-orang salih. Termasuk di dalam cakupan ungkapan 'orang yang diberi nikmat' ialah setiap orang yang diberi anugerah keimanan kepada Allah ta'ala, mengenal-Nya dengan baik, mengetahui apa saja yang dicintai-Nya, mengerti apa saja yang dimurkai-Nya, 
selain itu dia juga mendapatkan taufik untuk melakukan hal-hal yang dicintai tersebut dan meninggalkan hal-hal yang membuat Allah murka. Jalan inilah yang akan mengantarkan hamba menggapai keridhaan Allah ta'ala. Inilah jalan Islam. Islam yang ditegakkan di atas landasan iman, ilmu, amal dan disertai dengan menjauhi perbuatan-perbuatan syirik dan kemaksiatan. Sehingga dengan ayat ini kita kembali tersadar bahwa Islam yang kita peluk selama ini merupakan anugerah nikmat dari Allah ta'ala. Dan untuk bisa menjalani Islam dengan baik maka kita pun sangat membutuhkan sosok teladan yang bisa dijadikan panutan (lihat Aisarut Tafaasir, hal. 12).

Makna ayat ketujuh

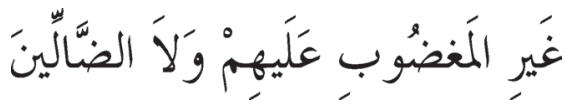

Artinya: "Bukan jalannya orang-orang yang dimurkai dan bukan pula jalan orang-orang yang tersesat."

Orang yang dimurkai adalah orang yang sudah mengetahui kebenaran akan tetapi tidak mau mengamalkannya. Contohnya adalah kaum Yahudi dan semacamnya. Sedangkan orang yang tersesat adalah orang yang tidak mengamalkan kebenaran gara-gara kebodohan dan kesesatan mereka. Contohnya adalah orang-orang Nasrani dan semacamnya. Sehingga di dalam ayat ini tersimpan motivasi dan dorongan kepada kita supaya menempuh jalan kaum yang shalih. Ayat ini juga memperingatkan kepada kita untuk menjauhi jalan yang ditempuh oleh orang-orang yang sesat dan menyimpang (lihat Aisarut Tafaasir, hal. 13 dan Taisir Karimir Rahman hal. 39).

Surat yang demikian ringkas ini sesungguhnya telah merangkum berbagai pelajaran yang tidak terangkum secara terpadu di dalam surat-surat yang lain di dalam Al Quran. Surat ini mengandung intisari ketiga macam tauhid. Di dalam penggalan ayat Rabbil alamiin terkandung makna tauhid rububiyah. Tauhid rububiyah adalah mengesakan Allah dalam hal perbuatanperbuatanNya seperti mencipta, memberi rezeki dan lain sebagainya. Di dalam kata Allah dan Iyyaaka na'budu terkandung makna tauhid uluhiyah. Tauhid uluhiyah adalah mengesakan Allah dalam bentuk beribadah hanya kepada-Nya. Demikian juga di dalam penggalan ayat Alhamdu terkandung makna tauhid asma' wa sifat. Tauhid asma' wa sifat adalah mengesakan Allah dalam hal nama-nama dan sifatsifatNya. Allah telah menetapkan sifatsifat kesempurnaan bagi diri-Nya sendiri. Demikian pula Rasul shallallahu'alaihi wa sallam. Maka kewajiban kita adalah mengikuti Allah dan Rasul-Nya dalam menetapkan sifat-sifat kesempurnaan itu benar-benar dimiliki oleh Allah. Kita mengimani ayat ataupun hadits yang berbicara tentang nama dan sifat Allah sebagaimana adanya, tanpa menolak maknanya ataupun menyerupakannya dengan sifat makhluk.

Selain itu surat ini juga mencakup intisari masalah kenabian yaitu tersirat dari ayat Ihdinash shirathal mustaqiim. Sebab jalan yang lurus tidak akan bisa ditempuh oleh hamba apabila tidak ada bimbingan wahyu yang dibawa oleh Rasul. Surat ini juga menetapkan bahwasanya amalamal hamba itu pasti ada balasannya. Hal ini tampak dari ayat Maaliki yaumid diin. Karena pada hari kiamat nanti amal hamba akan dibalas. Dari ayat ini juga bisa ditarik kesimpulan bahwa balasan yang diberikan itu berdasarkan prinsip keadilan, karena makna kata diin adalah balasan dengan adil. Bahkan di balik untaian ayat ini terkandung penetapan takdir. Hamba berbuat di bawah naungan takdir, bukan terjadi secara merdeka di luar takdir Allah ta'ala sebagaimana yang diyakini oleh kaum Qadariyah (penentang takdir). Dan menetapkan bahwasanya hamba memang benar-benar pelaku atas perbuatan-perbuatanNya. 
Hamba tidaklah dipaksa sebagaimana keyakinan kaum Jabriyah. Bahkan di dalam ayat Ihdinash shirathal mustaqiim itu terdapat intisari bantahan kepada seluruh ahli bid'ah dan penganut ajaran sesat. Karena pada hakikatnya semua pelaku kebid'ahan ${ }^{10}$ maupun penganut ajaran sesat itu pasti menyimpang dari jalan yang lurus; yaitu memahami kebenaran dan mengamalkannya.

Surat ini juga mengandung makna keharusan untuk mengikhlaskan ketaatan dalam beragama demi Allah ta'ala semata. Ibadah maupun isti'anah, semuanya harus lillaahi ta'aala. Kandungan ini tersimpan di dalam ayat Iyyaka na'budu wa iyyaaka nasta'iin (disadur dari Taisir Karimir Rahman, hal. 40). Allaahu akbar, sungguh menakjubkan isi surat ini. Maka tidak aneh apabila Rasulullah shallallahu 'alaihi wa sallam menyebutnya sebagai surat paling agung di dalam Al Quran. ${ }^{11}$ Ya Allah, karuniakanlah kepada kami ilmu yang bermanfaat. Jauhkanlah kami dari jalan orang yang dimurkai dan sesat. Sesungguhnya Engkau Maha Mendengar lagi Mengabulkan do'a. Wallahu a'lam bish shawaab.

\section{Konstruksi Teori Komunikasi}

Al Fatihah adalah surat dalam Al Qur'an yang dibaca setidaknya tujuh belas kali sehari oleh setiap muslim. Dalam sholat wajib yang meliputi Subuh, Dhuhur, Ashar, Magrib dan Isya setiap muslim membaca surat ini sebagai bacaan wajib yang harus ditunaikan. Al Fatihah adalah rukun sholat yang harus dibaca. Tanpa bacaan tersebut, sholat seseorang dianggap tidak sah. Kandungan utama surat Al Fatihah secara garis besar dibagi dalam dua hal yaitu, komunikasi antara manusia dengan Rab-nya dan juga

10 Bid'ah adalah membuat aturan yang baru dalam beragama yang tidak ada dasarnya dari Al Qur'an, Hadist, Ijma dan Qiyas. Bentuknya bisa dalam tata cara peribadatan atau hukum atau syariat yang lain. Agama islam telah sempurna sehingga tidak perlu penambahan atau pengurangan.

11 Abu Muslih Ari Wahyudi, Www.Muslim.Or.Id jawaban dari Rab-nya terhadap bacaan mahlukNya.

Hal tersebut tersurat dalam hadist berikut: dari Abu Hurairah, "Kalau kami sedang berada di belakang imam, bagaimana?" Beliau menjawab, "Bacalah untuk diri kalian sendiri, karena sesungguhnya aku mendengar Rasulullah shallallahu 'alaihi wa sallam bersabda, "Allah ta'ala berfirman: 'Aku membagi shalat (Al Fatihah) antara Aku dengan hamba-Ku menjadi dua bagian. Dan hamba-Ku akan mendapatkan apa yang dia minta.' Kalau hamba itu membaca, 'Alhamdulillahi Rabbil 'alamin', maka Allah ta'ala menjawab, 'Hamba-Ku telah memuji-Ku'. Kalau dia membaca, 'Ar Rahmanirrahim' maka Allah ta'ala menjawab, 'Hamba-Ku menyanjungKu'. Kalau ia membaca, 'Maliki yaumid din' maka Allah berfirman, 'Hamba-Ku mengagungkan Aku'. Kemudian Allah mengatakan, 'Hamba-Ku telah pasrah kepada-Ku'. Kalau ia membaca, 'Iyyaka na 'budu wa iyyaka nasta'in' maka Allah menjawab, 'Inilah bagian untuk-Ku dan bagian untuk hamba-Ku. Dan hamba-Ku pastiakan mendapatkan permintaannya.'. dan kalau dia membaca, 'Ihdinash shirathal mustaqim, shirathalladziina an'amta 'alaihim ghairil maghdhubi 'alaihim wa ladh dhaalliin" maka Allah berfirman, 'Inilah hak hamba-Ku dan dia akan mendapatkan apa yang dimintanya.'."

Hal tersebut mengisyaratkan adanya komunikasi transenden yang dibangun antara seorang muslim dengan Allah SWT. Kajian dasar yang membahas persoalan ini dalam ilmu komunikasi belum banyak dilakukan. Bidang kajian komunikasi selama ini dibatasi pada aspek human communication yang bersifat manifest. Pembahasan komunikasi dan teori yang melingkupi aspek praksis komunikasi didasarkan pada hubungan manifest yang dijalin oleh partisipan komunikasi. Kerangka imajiner dan relasi 
hubungan yang tidak bersifat manifest dianggap sebagai bagian terpisah dari proses komunikasi.

Dalam pandangan Islam kegiatan komunikasi tidak hanya membentuk pola hubungan antar manusia tetapi membentuk pola kedekatan hubungan antara manusia dengan Rab-nya. Sekulerisasi pemahaman untuk memisahkan kegiatan komunikasi antara manusia dengan manusia membuat pemahaman komunikasi terbatas pada aspek manifest. Pertanggungjawaban terbesar komunikasi manusia adalah dengan Rabnya sehingga pemahaman ini menjadi dasar dari kegiatan komunikasi dalam Islam. Berkomunikasi dengan sesama manusia tidak bisa dibatasi dengan penilaian aspek manifest semata.

Proses formulasi teori meliputi tahapan inquiri yaitu, asking question, observation dan formulating answer ${ }^{12}$. Proses inquiry, tak lebih dari proses menanyakan pertanyaan yang menarik, penting, dan selanjutnya menyediakan jawaban yang sistematis atas pertanyaan tersebut. Untuk meraih jawaban itu, diperlukan langkah kedua, yaitu observation (pengamatan). Dalam melakukan pengamatan, diperlukan metode yang berbeda-beda -seperti yang telah disebut sebelumnya- dari satu tradisi ke tradisi lainnya. Seorang peneliti haruslah merencanakan terlebih dahulu metode apa yang akan digunakannya, setelah ia melakukan tahapan berikutnya: asking question. Lalu tahap selanjutnya adalah constructing answers atau membangun jawaban. Dalam proses ketiga ini, para sarjana akan berusaha untuk mendefinisikan, mendeskripsikan, dan menelaskan, menilai, dan menginterpretasikan sesuatu yang diamati, yang akan sama dengan maksud dari "teori".

Proses penyelidikan ilmiah ini tidak berlangsung secara linier, melainkan melaju melingkar, maju mundur

12 Little john, theory of human communications dari pon ke poin. Misalnya, seorang sarjana komunikasi yang memiliki sebuah rancangan investigasi ilmiah tertentu, melakukan presentasi di hadapan para kolega dalam sebuah konvensi ilmiah. Proyeknya mendapatkan ulasan dari banyak pihak, sehingga ia dapat mengetahui letak kelemahan rancangan miliknya, dan barangkali terpaksa harus kembali ke poin awal. Atau maju ke depan, dan setelah hasil penelitian tercipta, akan tercipta pertanyaan-pertanyaan baru ${ }^{13}$.

Tafsir Surat Al Fatihah memberikan penjelasan dengan rinci mulai dari proses dasar keyakinan seorang muslim sampai dengan proses komunikasi antara manusia dengan Allah SWT. Merujuk pada proses inquiri dalam mewujudkan sebuah teori, tafsir yang diketengahkan sesungguhnya menjawab segala persoalan yang dihadapi manusia. Pada tataran ini AL Fatihah sebagai wahyu dari Allah SWT tidak bisa dipandang sebagai teori karena bukan sebuah hasil pemikiran manusia. Lebih bijaksana dan tepat ketika menyatakan bahwa dalam tafsir Al Fatihah terdapat ajaran Allah SWT tentang komunikasi.

Teori dan praktek komunikasi hanya menjadi bagian kecil dari keseluruhan sistem kehidupan manusia. Demikian halnya teori komunikasi bukanlah asas dari kehdiupan manusia secara absolut melainkan bagian kecil dari manifest eksistensi manusia. Problematika komunikasi antarmanusia sesungguhnya bisa diselesaikan dengan bijak ketika manusia memahami makna dari Al Qur'an. Sebagai bagian tak terpisahkan dari proses keberadaan manusia di dunia, kitab suci ini merupakan panduan perbuatan manusia dalam segala bidang.

\section{E. Kesimpulan}

1. Al Qur'an adalah wahyu Allah SWT yang diturunkan kepada manusia

13 http://kuliahnyapoundra.blogspot.com/ 
sebagai pedoman hidup dan jawaban segala persoalan hidup. Posisi Al Qur'an tidak tergantikan dengan pedoman hidup lainnya. Pada tata urutan penafsiran, ayat Al Qur'an ditafsirkan dengan ayat lain, ayat ditafsirkan dengan hadist, ayat ditafsirkan dengan perkataan atau penjelasan sahabat, dan bahasa Arab.

2. Sebagai pedoman hidup manusia kesempurnaan ayat-ayat Al Qur'an tidak terbantahkan. Di dalamnya terdapat aturan untuk mengatur semua aspek kehidupan manusia. Terdapat kumpulan kisah-kisah umat terdahulu untuk diambil suri tauladannya oleh manusia. Di dalam Al Qur'an juga terdapat kabar gembira bagi orang-orang yang beriman dan terdapat kabar yang menyedihkan bagi orang yang tidka beriman

3. Salah satu surat dalam Al Qur'an yang memiliki banyak pengaruh bagi kehidupan manusia adalah surat Al Fatihah. Surat ini wajib dibaca minimal tujuh belas kali sehari semalam oleh setiap muslim dalam sholatnya. Dalam surat ini digambarkan proses komunikasi antara hamba dengan Rab-Nya. Proses komunikasi transenden tersebut menjadi dasar pola komunikasi dari setiap muslim dengan orang lain.
4. Menggali potensi AL Qur'an sebagai rujukan dalam segala persoalan hidup manusia tidak bisa dilepaskan dari aspek keyakinan yang dianut oleh individu. Dalam persoalan komunikasi aspek praksis sebagai penerapan konsepsi yang diyakini oleh seorang muslim sarat dengan aturan dan dibubuhi dasar keyakinan keagamaannya. Nilai-nilai yang terkandung dalam Al Qur'an sebagai petunjuk hidup manusia menjadi dasar cara berkomunikasi dengan orang lain.

5. Bagiseorang muslimkeputusanuntuk melakukan atau tidak melakukan sesuatu didasarkan pada keyakinan syariat agama yang dianutnya. Karena itu tidak bisa dipisahkan pemikiran terhadap agama yang menjadi dasar berkomunikasi. Konstruksi teori komunikasi dalam pandangan Islam bukanlah sesuatu yang bebas nilai, melainkan sebuah konsepsi pendukung dan praktek yang semestinya sarat dengan nilainilai syariat Islam 


\section{Daftar Pustaka}

Al Qur'an dan Terjemahnya, 2007, Jakarta: Tiga Serangkai Pustaka Mandiri

Al Utsaimin, Muhammad bin Sholih, 2006, Ulasan Tuntas Tentang Tiga Prinsip Pokok, Darul Haq: Jakarta

Al Utsaimin, Muhammad bin Sholih, 2007, Syarh Riyadhis Shalihin karya AsySyaikh Muhammad bin Shalih AlUtsaimin terbitan Darus Salam - Mesir, diterjemahkan Abu Umar Urwah AlBankawy, muraja'ah dan catatan kaki: Al-Ustadz Abu Abdillah Muhammad Rifai

Moleong, Lexy, 2008, Metode Penelitian Kualitatif, Remaja Rosda Karya:Bandung

Rahardjo, Turnomo. (2009). Cetak Biru Teori Komunikasi dan Studi Komunikasi di Indonesia, makalah dalam Simposium Nasional: Arah Depan Pengembangan Ilmu Komunikasi di Indonesia, Jakarta.

Rahardjo, Turnomo. 2012. Konstruksi Teori Komunikasi Berbasis Kearifan Lokal,

Sihombing, Emrus, 2012, Membangun Teori Komunikasi Berbasis Riset Komunikasi Ke-Indonesia-An, dalam Prosiding Konferensi Nasional Ilmu Komunikasi, UPH Press: Jakarta, hal 354-380

Utari, Prahastiwi, 2012, Make A Dream Comes True, Membumikan Teori Komunikasi Indonesia, dalam Prosiding Konferensi Nasional Ilmu Komunikasi, UPH Press: Jakarta, hal 444-462

\section{Sumber Internet}

Ahmad Supardi Hasibuan, MA, PERANAN ASBABUN NUZUL DALAM MEMAHAMI AL-QUR'AN, http://riau.kemenag.go.id/ index.php? $\mathrm{a}=$ artikel\&id $=10114$

http://belajar-islamic.blogspot.com/2011/07/ asbabun-nuzul-sebab-sebab-turunnya.html

http://kuliahnyapoundra.blogspot.com/

http://www.elfawaz.com/

http:/muslim.or.id 